\title{
ASSESSMENT OF SUBCLINICAL ATHEROSCLEROSIS IN PATIENTS WITH HIDRADENITIS SUPPURATIVA AND ITS RELATION TO C-REACTIVE PROTEIN
}

By

\author{
Sara Ahmed Galal, Eslam Mahmoud Mohammed, Abeer Mostafa Kamel \\ and Hala Maghraby Maghraby*
}

Department of Dermatology \& Venereology and *Radiodiagnosis, Faculty of Medicine for (Girls), Cairo, Al-Azhar University, Egypt

Corresponding author: Sara Ahmed Galal, E-mail: drsaragalal@azhar.edu.eg

\begin{abstract}
Background: Hidradenitis suppurativa (HS) is a chronic, inflammatory, recurring dermatosis of the hair follicle. Some studies have revealed relation between HS and other diseases as metabolic syndrome, multifaceted disorder associated with increased risk for subclinical atherosclerosis and cardiovascular disease (CVD).

Objective: To measure carotid artery intima-media thickness (CIMT) as predictors of cardiovascular risk in HS patients and its relation to inflammatory serum marker especially $\mathrm{C}$-reactive protein (CRP).

Patients and Method: This was a prospective case-control performed on 20 patients with HS and compared to 20 healthy volunteers matched in sex, mean of the age and BMI. Participants were recruited from Outpatient clinic of Al-Zahra'a University Hospital during the period from March 2017 to December 2018. The following investigations were done to all the participants including CRP, ESR, neutrophils count, HDL, total cholesterol, triglycerides and glucose. Carotid intima media thickness with B-mode ultrasound.

Conclusion: CIMT measurement was not significantly different between patients and controls but differed significantly according to stage of the disease, so HS potentially increased the risk of cardiovascular. The thickness of CIMT related directly to inflammatory serum markers especially CRP, so CRP was considered marker of disease severity and can be used for monitoring the response of treatment.
\end{abstract}

Key words: Hidradenitis suppurativa, subclinical atherosclerosis, cardiovascular disease, carotid intimamedia thickness, carotid ultrasonography.

\section{INTRODUCTION}

Hidradenitis suppurativa (HS) is a recurrent chronic inflammatory debilitating skin disease of the hair follicle. It presents with inflamed painful, deep-seated lesions in the apocrine bearing areas, usually affect the inguinal, anogenital regions and axillae (Nguyen and Damiani, 2021). The prevalence rate of HS in the general population from 0.05 to 4\% (Zouboulis et al., 2015).

Chronic inflammatory diseases such as rheumatoid arthritis, psoriasis and ankylosing spondylitis have been associated with sub clinical atherosclerosis (Gonzalez-Lopez et al., 2016, Arida et al., 2018 and Peluso et al., 2019). 
HS is associated with several comorbidities, including subclinical atherosclerosis, cardiovascular disease, metabolic syndrome, diabetes, osteoarthritis or inflammatory bowel disease (Kohorst et al., 2015 and Montero-Vilchez et al., 2021).

Some reported systematic reviews indicates that CVD risk factors appear at significantly higher rate in patients with HS compared with control subjects (Tzellos et al., 2015).

There are many non-invasive tools that have been found useful to detect the presence of subclinical atherosclerosis in patients with chronic inflammatory diseases ( $\mathrm{Li}$ et al., 2021). The measurement of CIMT by carotid ultrasound is one of these tools (Kerekes et al., 2012).

The present study was done for detection of cardiovascular risk in patients with HS and the relation between them and inflammatory serum markers through evaluation of CIMT by carotid ultrasound and lab measurement of CRP, ESR and neutrophil level.

The aim of the present work was to assess the prevalence of subclinical atherosclerosis in HS patients and the relation of $\mathrm{C}$ reactive protein to $\mathrm{HS}$ severity and incidence of sub-clinical atherosclerosis.

\section{PATIENTS AND METHODS}

This prospective case-control study has been conducted on 20 patients with hidradenitis suppurativa as a patient's group and 20 age and sex-matched healthy volunteers as a control group. Participants were recruited from Outpatient clinic of
Al-Zahra'a University Hospital during the period from March 2017 to December 2018.

The included cases have been clarified about the aim and the procedure of this study, and informed consent approved by the research ethics committee of the Faculty of Medicine, Al-Azhar University Hospitals, was obtained from every participant prior to study initiation.

Exclusion criteria: Patients' history of CVD, including ischemic heart disease, heart failure, cerebrovascular accidents, or peripheral arterial disease. Diabetes mellitus patients, obesity and dyslipidemia and chronic kidney disease. Patients with chronic kidney disease, presence of concomitant inflammatory diseases (rheumatoid arthritis and inflammatory bowel disease) or other chronic skin diseases.

\section{All cases were subjected to:}

Complete history taking: Age of onset, duration of the disease, family history of HS and risk factors. History of chronic heart disease, diabetes mellitus or chronic kidney diseases or any other chronic disease

Weight, height, and abdominal circumference of participants have been measured, and their body mass index (BMI) have been calculated according to the following formula (weight in $\mathrm{kg}$ / height in m2) (MacKay 2010).

Dermatological examination: To determine the presence of other skin diseases and to score the degree of severity of the disease was according to; Hurley staging system (Zouboulis et al., 2015). 


\section{ASSESSMENT OF SUBCLINICAL ATHEROSCLEROSIS IN PATIENTS...}

Blood sampling: for assessment of Neutrophils count, C-Reactive Protein (CRP) level, erythrocyte sedimentation rate (ESR), FBG, high density lipoprotein, triglycerides, and serum creatinine.

\section{Radiological}

investigations:

Measurement of carotid artery intimamedia thickness (CIMT) by Doppler. All patients were underwent to Dupler examination at Radiology Department of Al-Zahraa University Hospital using Esaote My Lab ${ }^{\mathrm{TM}} 50$ machine, (made in Italy) a high-frequency linear array probe $7 \mathrm{MHz}$ is used.

The patient was examined in a supine position and the head extended and inclined by about 30 with a pillow under it. The intima-media complex (IMC) composed of two layers, the hyperechoic layer closer to the vascular lumen and the hypoechoic layer. Depiction of IMC was taken in B-mode gray scale along the posterior wall of CCA and the minimum unit of IMT measurement was $0.1 \mathrm{~mm}$.

Mean IMT measurement of mean IMT was performed on the right and left common carotid artery. The cut points for intima-media thickness between normal and abnormal populations have varied among reported studies and, therefore, it was difficult to establish a single cut point that defines abnormality. CIMT of $0.9 \mathrm{~mm}$ or more was abnormal and likely to be associated with sonographically plaque.

\section{Statistical design:}

Quantitative data were expressed in term of mean $\pm(\mathrm{SD})$ and median, independent $\mathrm{T}$-test and ANOVA were used to study the difference in parametric continuous variables while, Mann Whitney and Kruskal Wallis tests were used for non-parametric data. Qualitative data were expressed in number and percentage. Chi square-test, Fisher's Exact or Monte Carlo corrections were used for comparison between groups. Pearson correlation test was done to assess relation between CIMT with duration and ESR in patients' group. Significance level was taken at a P-value $\leq 0.05$. SPSS, version 20 was used for data analysis.

\section{RESULTS}

Descriptive data of the studied groups in our study showed that the age of patients and control ranged from 20 to 55 years (mean \pm SD: $38.45 \pm 10.78$ years) with no statistically significant difference. There was no statically significant difference regard, sex and BMI both patient and control group.

As regard smoking 7 out of 20 patients $(35 \%)$ were smokers and $13(65 \%)$ were nonsmokers. while the controls were nonsmokers $(\mathrm{P}=0.008)$.

In patient group 5 patients $(25 \%)$ had positive family history of HS, while the control group showed negative family history for HS ( $\mathrm{P}=0.047)$.

Regarding serum creatinine, serum lipid profile and fasting blood glucose there was no statically significant difference between patient and control groups.

There was no statically significance difference between patients and control regarding TG, HDL, LDH and Total cholesterol level (Table 1).

It was noticed that neutrophils showed statically significant difference between patient and control groups (Table 1). 
SARA AHMED GALAL et al.,

Table (1): Comparison between the two studied groups according to laboratory investigations

\begin{tabular}{|c|c|c|c|c|c|}
\hline \multirow{2}{*}{$\begin{array}{ll}\text { Parameters } & \text { Groups } \\
\end{array}$} & \multicolumn{2}{|c|}{ Cases $(\mathrm{n}=\mathbf{2 0})$} & \multicolumn{2}{|c|}{ Control $(n=20)$} & \multirow[t]{2}{*}{$\mathbf{P}$} \\
\hline & No. & $\%$ & No. & $\%$ & \\
\hline $\begin{array}{c}\text { Serum Creatinine }(\mathbf{m g} / \mathbf{d l}) \\
\text { Less than } 1.3 \\
\text { More than } 1.3\end{array}$ & $\begin{array}{c}20 \\
0\end{array}$ & $\begin{array}{c}100.0 \\
0.0\end{array}$ & $\begin{array}{c}20 \\
0\end{array}$ & - & - \\
\hline $\begin{array}{l}\text { Min. }- \text { Max. } \\
\text { Mean } \pm \text { SD. } \\
\text { Median }\end{array}$ & \multicolumn{2}{|c|}{$\begin{array}{l}0.60-1.20 \\
0.89 \pm 0.18 \\
0.85\end{array}$} & \multicolumn{2}{|c|}{$\begin{array}{c}0.50-1.20 \\
0.90 \pm 0.25 \\
1.0 \\
\end{array}$} & 0.886 \\
\hline $\begin{array}{c}\text { Triglycerides (mg/dl) } \\
\text { Normal } \\
\text { Abnormal } \\
\end{array}$ & $\begin{array}{c}20 \\
0\end{array}$ & $\begin{array}{c}100.0 \\
0.0\end{array}$ & $\begin{array}{c}20 \\
0\end{array}$ & - & - \\
\hline $\begin{array}{l}\text { Min. -Max. } \\
\text { Mean } \pm \text { SD. } \\
\text { Median } \\
\text { Mean rank }\end{array}$ & \multicolumn{2}{|c|}{$\begin{array}{c}89.0-130.0 \\
110.10 \pm 11.19 \\
111.0 \\
23.9\end{array}$} & \multicolumn{2}{|c|}{$\begin{array}{c}95.0-138.0 \\
115.80 \pm 12.58 \\
116.50 \\
25.1\end{array}$} & 0.138 \\
\hline $\begin{array}{l}\text { HDL } \\
\text { Min. - Max. } \\
\text { Mean } \pm \text { SD. } \\
\text { Median }\end{array}$ & \multicolumn{2}{|c|}{$\begin{array}{c}45.0-90.0 \\
64.80 \pm 13.07 \\
63.50\end{array}$} & \multicolumn{2}{|c|}{$\begin{array}{c}48.0-80.0 \\
64.0 \pm 10.11 \\
61.0\end{array}$} & 0.830 \\
\hline $\begin{array}{c}\text { LDL } \\
\text { Min. - Max. } \\
\text { Mean } \pm \text { SD. } \\
\text { Median }\end{array}$ & \multicolumn{2}{|c|}{$\begin{array}{c}55.0-95.0 \\
73.60 \pm 12.47 \\
70.0\end{array}$} & \multicolumn{2}{|c|}{$\begin{array}{c}55.0-91.0 \\
74.15 \pm 11.46 \\
71.50\end{array}$} & 0.885 \\
\hline $\begin{array}{c}\text { Total Cholesterol (mg/dl) } \\
\text { Normal } \\
\text { Abnormal } \\
\end{array}$ & $\begin{array}{c}20 \\
0\end{array}$ & $\begin{array}{c}100.0 \\
0.0\end{array}$ & $\begin{array}{c}20 \\
0 \\
\end{array}$ & - & - \\
\hline $\begin{array}{c}\text { Min. -Max. } \\
\text { Mean } \pm \text { SD. } \\
\text { Median } \\
\end{array}$ & \multicolumn{2}{|c|}{$\begin{array}{c}100.0-170.0 \\
138.40 \pm 20.69 \\
140.0 \\
\end{array}$} & \multicolumn{2}{|c|}{$\begin{array}{c}103.0-170.0 \\
138.35 \pm 17.88 \\
140.50 \\
\end{array}$} & 0.994 \\
\hline $\begin{array}{c}\text { FBG (mg/dl) } \\
\text { Normal } \\
\text { Abnormal } \\
\end{array}$ & $\begin{array}{l}16 \\
4\end{array}$ & $\begin{array}{l}80.0 \\
20.0\end{array}$ & $\begin{array}{c}20 \\
0\end{array}$ & 0.106 & 0.106 \\
\hline $\begin{array}{l}\text { Min. -Max. } \\
\text { Mean } \pm \text { SD. } \\
\text { Median } \\
\end{array}$ & \multicolumn{2}{|c|}{$\begin{array}{c}70.0-110.0 \\
91.20 \pm 12.50 \\
90.0 \\
\end{array}$} & \multicolumn{2}{|c|}{$\begin{array}{c}77.0-93.0 \\
86.55 \pm 5.50 \\
88.0 \\
\end{array}$} & 0.140 \\
\hline $\begin{array}{c}\text { Neutrophils } \\
\text { Not } \\
\text { Elevated }\end{array}$ & $\begin{array}{c}14 \\
6\end{array}$ & $\begin{array}{l}70.0 \\
30.0\end{array}$ & $\begin{array}{c}20 \\
0\end{array}$ & $0.020 *$ & 0.020 \\
\hline $\begin{array}{l}\text { Min. -Max. } \\
\text { Mean } \pm \text { SD. } \\
\text { Median }\end{array}$ & \multicolumn{2}{|c|}{$\begin{array}{c}0.55-0.85 \\
0.67 \pm 0.10 \\
0.62 \\
\end{array}$} & \multicolumn{2}{|c|}{$\begin{array}{c}0.55-0.67 \\
0.60 \pm 0.04 \\
0.60 \\
\end{array}$} & 0.014 \\
\hline
\end{tabular}

*: Statistically significant 
Measurement of CIMT (considered thick if $\geq 1 \mathrm{~mm}$ ):

In patient group: 3 patients with CIMT $\geq 1 \quad \mathrm{~mm} \quad(15 \%)$ and $17 \quad(85 \%)$ patients with CIMT $<1 \mathrm{~mm}$. Measurement of CIMT ranged between 0.6 to $1.2 \mathrm{~mm}$ (Mean \pm SD: $0.78 \pm 0.17$ ).

In control group: all patients measurement was $<1 \mathrm{~mm}$. The measurement ranged between 0.4 to 0.8 mm with (Mean \pm SD: $0.68 \pm 0.09$ ).

There was no statistically significant difference between patient and control regarding CIMT ( $\mathrm{p}=0.231$ ) (Table 2).

\section{Concerning $C$ reactive protein:}

In the patient group: Six patient $(30 \%)$ showed elevated CRP (Mean \pm SD: $7.33 \pm$ 1.63).
In control group: All of them showed normal CRP. with a statistically clinical significance $\mathrm{p}=0.020$ (Table 2).

There was a statistically significant difference between patient and control regarding elevated CRP $(\mathrm{p}=.020)$ (Table 2).

Erythrocyte sedimentation rate (ESR):

In patient group: ESR ranged from 4 to 55 (Mean \pm SD: $24.10 \pm 17.53)$.

In controls: It ranged from 3 to 9 (Mean \pm SD: $6.15 \pm 1.87$ ).

There was a statistically significant difference between patient and control regarding ESR level $(\mathrm{p}<0.001)$ (Table 2).

Table (2): Comparison between the two studied groups according to CIMT, CRP and ESR

\begin{tabular}{|c|c|c|c|c|c|}
\hline \multirow{2}{*}{ Parameters $\quad$ Groups } & \multicolumn{2}{|c|}{ Cases $(n=20)$} & \multicolumn{2}{|c|}{ Control $(\mathrm{n}=\mathbf{2 0})$} & \multirow[t]{2}{*}{$\mathbf{P}$} \\
\hline & No. & $\%$ & No. & $\%$ & \\
\hline $\begin{array}{c}\text { Carotid artery intima median } \\
\text { thickness CIMT }(\mathbf{m m}) \\
\text { Absent }(<0.8) \\
\text { Present }(\geq 0.8)\end{array}$ & 146 & $\begin{array}{l}70.0 \\
30.0\end{array}$ & $\begin{array}{c}18 \\
2\end{array}$ & 90.010 .0 & 0.235 \\
\hline $\begin{array}{l}\text { Absent }(<1) \\
\text { Present }(>1)\end{array}$ & $\begin{array}{c}17 \\
3\end{array}$ & $\begin{array}{l}85.0 \\
15.0\end{array}$ & 200 & 100.00 .0 & 0.231 \\
\hline $\begin{array}{l}\text { Min. - Max. } \\
\text { Mean } \pm \text { SD. } \\
\text { Median }\end{array}$ & \multicolumn{2}{|c|}{$\begin{array}{c}0.60-1.20 \\
0.78 \pm 0.17 \\
0.70\end{array}$} & \multicolumn{2}{|c|}{$\begin{array}{c}0.40-0.80 \\
0.68 \pm 0.09 \\
0.70\end{array}$} & $0.025 *$ \\
\hline $\begin{array}{c}\text { CRP } \\
\text { Normal } \\
\text { Elevated } \\
\end{array}$ & 146 & $\begin{array}{l}70.0 \\
30.0\end{array}$ & 200 & 100.00 .0 & $0.020^{*}$ \\
\hline $\begin{array}{l}\text { Min. - Max. } \\
\text { Mean } \pm \text { SD } \\
\text { Median }\end{array}$ & \multicolumn{2}{|c|}{$\begin{array}{c}5.0-9.0 \\
7.33 \pm 1.63 \\
7.50\end{array}$} & \multicolumn{2}{|c|}{--- } & - \\
\hline $\begin{array}{c}\text { ESR } \\
\text { Min. - Max. } \\
\text { Mean } \pm \text { SD } \\
\text { Median } \\
\text { Mean rank }\end{array}$ & \multicolumn{2}{|c|}{$\begin{array}{c}4.0-55.0 \\
24.10 \pm 17.53 \\
20.0 \\
27.8\end{array}$} & \multicolumn{2}{|c|}{$\begin{array}{c}3.0-9.0 \\
6.15 \pm 1.87 \\
6.0 \\
13.2\end{array}$} & $\mathrm{P}=0.000^{*}$ \\
\hline
\end{tabular}

*: Statistically significant 
There was a statistically significant relation between Hulry staging and age, duration, smoking, family history, and
BMI in the patient group, while there was no statistically significant relation between Hulry stage and sex (Table 3).

Table (3): Relation between Hulry stage and different parameters in patients' group $(n=20)$

\begin{tabular}{|c|c|c|c|c|c|c|c|}
\hline \multirow{2}{*}{ Parameters } & \multicolumn{2}{|c|}{$\begin{array}{c}I \\
(n=7)\end{array}$} & \multicolumn{2}{|c|}{$\begin{array}{c}\text { II } \\
(n=7)\end{array}$} & \multicolumn{2}{|c|}{$\begin{array}{c}\text { III } \\
(n=6)\end{array}$} & \\
\hline & No. & $\%$ & No. & $\%$ & No. & $\%$ & \\
\hline $\begin{array}{c}\text { Sex } \\
\text { Male } \\
\text { Female } \\
\end{array}$ & 52 & $\begin{array}{l}71.4 \\
28.6 \\
\end{array}$ & 52 & $\begin{array}{l}71.4 \\
28.6 \\
\end{array}$ & 1.000 & $\begin{array}{l}83.3 \\
16.7 \\
\end{array}$ & 1.000 \\
\hline $\begin{array}{c}\text { Age (years) } \\
\text { Min. - Max. } \\
\text { Mean } \pm \text { SD. } \\
\text { Median }\end{array}$ & \multicolumn{2}{|c|}{$\begin{array}{c}20.0-43.0 \\
29.0 \pm 8.35 \\
27.0\end{array}$} & \multicolumn{2}{|c|}{$\begin{array}{c}25.0-51.0 \\
39.14 \pm 8.03 \\
39.0\end{array}$} & \multicolumn{2}{|c|}{$\begin{array}{c}42.0-55.0 \\
48.67 \pm 5.43 \\
50.50\end{array}$} & $\mathrm{P}=0.001$ \\
\hline $\begin{array}{c}\text { Duration (years) } \\
\text { Min. - Max. } \\
\text { Mean } \pm \text { SD. } \\
\text { Median }\end{array}$ & \multicolumn{2}{|c|}{$\begin{array}{c}2.0-7.0 \\
4.86 \pm 1.95 \\
5.0\end{array}$} & \multicolumn{2}{|c|}{$\begin{array}{c}6.0-11.0 \\
8.29 \pm 1.60 \\
8.0\end{array}$} & \multicolumn{2}{|c|}{$\begin{array}{c}13.0-18.0 \\
16.0 \pm 2.0 \\
16.0\end{array}$} & $<0.001$ \\
\hline $\begin{array}{l}\text { Smoking } \\
\text { Negative } \\
\text { Positive }\end{array}$ & 70 & $\begin{array}{c}100.0 \\
0.0\end{array}$ & 52 & $\begin{array}{l}71.4 \\
28.6\end{array}$ & $0.005^{*}$ & $\begin{array}{l}16.7 \\
83.3\end{array}$ & 0.005 \\
\hline $\begin{array}{l}\text { Family history } \\
\text { Negative } \\
\text { Positive }\end{array}$ & 70 & 1000.0 & 70 & $\begin{array}{c}100.0 \\
0.0\end{array}$ & $<0.001 *$ & $\begin{array}{l}16.7 \\
83.3\end{array}$ & $<0.001$ \\
\hline $\begin{array}{c}\text { BMI } \\
\text { Min. - Max. } \\
\text { Mean } \pm \text { SD. } \\
\text { Median }\end{array}$ & \multicolumn{2}{|c|}{$\begin{array}{c}19.0-25.0 \\
21.57 \pm 2.23 \\
21.0\end{array}$} & \multicolumn{2}{|c|}{$\begin{array}{c}21.0-27.0 \\
23.86 \pm 2.54 \\
24.0\end{array}$} & \multicolumn{2}{|c|}{$\begin{array}{c}23.0-30.0 \\
25.83 \pm 3.06 \\
25.0\end{array}$} & 0.030 \\
\hline
\end{tabular}

By post hoc test: regarding age: Stage I is statistically significant with stage III (sig=0.001) but not stage II (sig=0.1). Stage II is not statistically 


\section{ASSESSMENT OF SUBCLINICAL ATHEROSCLEROSIS IN PATIENTS...

There was a statistically significant duration of HS, family history, smoking, relation between CIMT and Hulry stage, CRP, neutrophils and ESR (Table 4).

Table (4): Relation between CIMIT and different parameters in patients' group ( $n=$ 20)

\begin{tabular}{|c|c|c|c|c|c|}
\hline \multirow{2}{*}{$\mathrm{P}_{\text {Parameters }}^{\text {CIMT }}$} & \multicolumn{2}{|c|}{ Absent $(<1)(n=17)$} & \multicolumn{2}{|c|}{ Present $(>=1)(n=3)$} & \\
\hline & No. & $\%$ & No. & $\%$ & \\
\hline \begin{tabular}{|c|} 
Hulry stage \\
I \\
II \\
III \\
\end{tabular} & $\begin{array}{c}77 \\
3\end{array}$ & $\begin{array}{c}41.241 .2 \\
17.6\end{array}$ & $\begin{array}{c}00 \\
3\end{array}$ & $\begin{array}{c}0.0 \\
0.0 \\
100.0\end{array}$ & 0.015 \\
\hline $\begin{array}{c}\text { CRP } \\
\text { Negative } \\
\text { Positive }\end{array}$ & $\begin{array}{c}14 \\
3\end{array}$ & 82.417 .6 & $\begin{array}{l}0 \\
3\end{array}$ & 0.0100 .0 & 0.018 \\
\hline $\begin{array}{l}\text { Neutrophils } \\
\text { Not Elevated } \\
\text { Elevated }\end{array}$ & $\begin{array}{c}14 \\
3\end{array}$ & 82.417 .6 & $\begin{array}{l}0 \\
3\end{array}$ & 0.0100 .0 & 0.018 \\
\hline $\begin{array}{c}\text { Smoking } \\
\text { Negative } \\
\text { Positive } \\
\end{array}$ & $\begin{array}{c}13 \\
4 \\
\end{array}$ & $\begin{array}{l}76.5 \\
23.5 \\
\end{array}$ & $\begin{array}{l}0 \\
3 \\
\end{array}$ & $\begin{array}{c}0.0 \\
100.0 \\
\end{array}$ & 0.031 \\
\hline $\begin{array}{c}\text { Family history } \\
\text { Negative } \\
\text { Positive } \\
\end{array}$ & $\begin{array}{c}15 \\
2\end{array}$ & 88.211 .8 & $\begin{array}{l}0 \\
3\end{array}$ & 0.0100 .0 & 0.009 \\
\hline $\begin{array}{c}\text { Duration (years) } \\
\text { Min. - Max. } \\
\text { Mean } \pm \text { SD. } \\
\text { Median }\end{array}$ & \multicolumn{2}{|c|}{$\begin{array}{c}2.0-18.0 \\
8.12 \pm 4.20 \\
7.0\end{array}$} & \multicolumn{2}{|c|}{$\begin{array}{c}15.0-18.0 \\
16.67 \pm 1.53 \\
17.0\end{array}$} & 0.017 \\
\hline $\begin{array}{c}\text { ESR } \\
\text { Min. - Max. } \\
\text { Mean } \pm \text { SD. } \\
\text { Median }\end{array}$ & \multicolumn{2}{|c|}{$\begin{array}{c}4.0-53.0 \\
19.53 \pm 14.62 \\
18.0\end{array}$} & \multicolumn{2}{|c|}{$\begin{array}{l}45.0-55.0 \\
50.0 \pm 5.0 \\
50.0\end{array}$} & 0.013 \\
\hline
\end{tabular}

There was a positive correlation between CIMT with both duration of HS, and the increase of ESR level (Table 5).

Table (5): Correlation between CIMT with duration and ESR in patients' group ( $n=$ 20)

\begin{tabular}{|c|c|c|}
\hline CIMT & R & P \\
\hline Duration (years) & 0.719 & $<0.001$ \\
\hline ESR & 0.750 & $<0.001$ \\
\hline
\end{tabular}

r: Pearson coefficient 


\section{DISCUSSION}

There was no statically significant difference between patient and control group regarding age, sex and BMI as both groups were cross matched.

Positive family history in patients with HS was significantly higher in patients than control; it suggested that genetic factors play a role in causing HS. Different mutations located at the $\gamma$ secretase gene have been identified in six Han-Chinese HS families, with all afflicted members of the families carrying the mutation in agreement with studies done by (Wang et al., 2010, Jemec et al., 2012 and Pink et al., 2013).

There was no clinical difference between patient and control as regard serum lipid profile in contrast to study done by Gonzalz Lopezet al. (2016) who found a relation between them. This explained by that in our study we excluded any member with dyslipidemia to detect the relation between CIMT and inflammatory serum markers with $\mathrm{HS}$ as dyslipidemia, if present, may be the cause of subclinical atherosclerosis and not the inflammatory state of the disease.

Regarding serum creatinine, serum lipid profile and fasting blood glucose, there was no statistically significant difference between patient and control groups as any member with abnormal measurement was excluded.

This study showed no significant difference between patient and control group as regard CIMT measurement in contrast to study done by Gonzalz Lopezet al. (2016) in which patients had greater carotid intima-media thickness values than control subjects. Despite this, the CIMT differed significantly according to Hurly staging, the thickness increased with the increase of the stage of HS indicating that HS may considered a risk factor for development of atherosclerosis in the future.

Our study CRP and ESR significantly higher in patient with HS. This agreed with Jiménez-Gallo et al. (2017) study. Yayan (2012) observed increased CRP in one third of patients with acute coronary heart disease which indicate that CRP could be a strong predictor of increased risk cardiovascular in healthy individuals.

CRP and ESR considered early biomarkers that indicate the onset of systemic inflammation in HS (JiménezGallo et al., 2017).

This study showed that there is relation between CIMT and CRP this agreed with study done by Tkahashi et al. (2014) that detected increase serum CRP level in patients with psoriasis (HS and psoriasis both are auto inflammatory chronic skin diseases).

In our study neutrophilic counts significantly higher in patient with HS. This increased neutrophilic counts and activation could consider HS a neutrophilic disorder (Jiménez-Gallo et al., 2017).

CIMT thickness in HS related significantly with elevated level of neutrophils. Baetta et al. (2010) postulate that neutrophils have causative role in atherogenesis and its progression.

CIMT correlated significantly with the duration of the disease increasing duration associated with increase of systemic inflammatory load. Gonzalez et al. (2016) 
suggested that ESR and CRP play role in both HS and CVD.

CIMT significant relation with the incidence of smoking and hidradenitis suppurativa. This is explained by that smoking is considered not only a risk factor for CVD but also for HS. This agreed with Micheletti et al. (2014) who stated that many factors associated with HS, which includes smoking.

There was a significant relation between CIMT and family history of hidradenitis suppurativa which can be explained by genetics role in pathogenesis of both (Gonzalz, Lopezet al., 2016).

In this study there was a relation between Hulry staging with age of the patient and duration of the HS which could be attributed to increase disease activity and inflammatory load with the increase of duration of the disease.

No change in the disease severity was detected according to sex of the patients which mean that sex hormones do not play role in disease severity in contrast to study done by Vazquez et al. (2013), Jorgensen et al. (2020) and Kirby et al. (2021) this difference between both studies can be explained by limited number of our study participants.

In this study there is significant relation between disease severity and smoking in agreement with study done by Vazquez et al. (2013) and Kohorst et al. (2015). Smoking is considered an important external risk factor for HS. Nicotine causes hyperplasia of infundibular keratinocytes and activation of a many of immune cells. The immunological response led to production of pro-inflammatory cytokines includes interleukin IL-1, IL-8, tumor necrosis factor- $\alpha$ (TNF- $\alpha)$ and stimulation of the Th17 cell (Prens et al., 2015).

The groups in our study according to inflammatory serum markers (CRP, ESR and neutrophils) showed significant difference which denoted that inflammatory serum makers especially CRP increased in patient with HS disease. Interestingly CRP, ESR and neutrophils increased significantly with the increase of the severity of hidradenitis suppurativa in agreement with study done by Hesham et al. (2015) with significant positive correlations among CRP and neutrophil count with HS Score.

\section{CONCLUSION}

CIMT measurement was not significantly different between patients and controls but differed significantly with the severity of the disease. Inflammatory serum markers (CRP, ESR and neutrophils) were significantly different according to the stage of the disease. So, these serum markers can be used as indicator for the severity of the disease, and for follow up of the response to treatment.

\section{REFERENCES}

1. Arida A, Protogerou AD, Kitas GD and Sfikakis PP (2018): Systemic Inflammatory Response and Atherosclerosis: The Paradigm of Chronic Inflammatory Rheumatic Diseases. International journal of molecular sciences., 19(7), 1890. https://doi.org/10.3390/ijms19071890

2. Baetta $\mathbf{R}$ and Corsini A (2010): Role of polymorphonuclear neutrophils in atherosclerosis: current state and future perspectives. Atherosclerosis; 210(1): 1-13.

3. González-López MA, Hernández JL, Lacalle M, Mata C, López-Escobar M, López-Mejías R, Portilla V and Fuentevilla 
P (2016): Increased prevalence of subclinical atherosclerosis in patients with hidradenitis suppurativa (HS). J Am Acad Dermatol., 75(2): 329-335.

4. Hessam $S, S$ and $M$, Gambichler $T$ and Bechara FG (2015): Correlation of inflammatory serum markers with disease severity in patients with hidradenitis (HS). J Am Acad Dermatol., 73(6):998-1005.

5. Jemec GB (2012): Clinical practice. Hidradenitis suppurativa. N Engl J Med., 366(2):158-164.

6. Jiménez-Gallo $D$, de la Varga-Martínez $R$, Ossorio-García L, Albarrán-Planelles C, Rodríguez C, Linares-Barrios M. (2017): The Clinical Significance of Increased Serum Proinflammatory Cytokines, C-Reactive Protein, and Erythrocyte Sedimentation Rate in Patients with Hidradenitis Suppurativa. Mediators Inflamm., 2450401. doi: $10.1155 / 2017 / 2450401$.

7. Jørgensen AR, Holm JG, Ghazanfar MN, Yao Y, Ring HC, Thomsen SF. (2020): Factors affecting quality of life in patients with hidradenitis suppurativa. Arch Dermatol Res., 312(6):427-436. doi: 10.1007/s00403019-02025-5.

8. Kerekes G, Soltész P, Nurmohamed MT, Gonzalez-Gay MA, Turiel M, Végh E and Shoenfeld Y (2012): Validated methods for assessment of subclinical atherosclerosis in rheumatology. Nat Rev Reumatol., 8:224-234.

9. Kirby JS, Hereford B, Thorlacius L, Villumsen B, Ingram JR, Garg A, Butt M, Esmann S, King T, Tan J, Jemec GBE. (2021): Validation of global item for assessing impact on quality of life of patients with hidradenitis suppurativa. $\mathrm{Br} \mathrm{J}$ Dermatol., 184(4):681-687. doi: 10.1111/bjd.19344.

10. Kohorst JJ, Kimball AB and Davis MD (2015): Systemic associations of hidradenitis suppurativa. J Am Acad Dermatol., 37: S72S35.

11. Li H, Xu X, Luo B and Zhang Y (2021): The Predictive Value of Carotid Ultrasonography With Cardiovascular Risk Factors-A "SPIDER" Promoting
Atherosclerosis. Front. Cardiovasc. Med., 8:706490. doi: 10.3389/fcvm.2021.706490

12. MacKay N (2010): Scaling of human body mass with height: the body mass index revisited. J Biomech., 43(4):764-766.

13. Micheletti RG (2014): Hidradenitis Suppurativa: current views on epidemiology, pathogenesis, and pathophysiology. Semin Cutan Med Surg., 33(Suppl 3):S48-S50.

14. Montero-Vilchez T., Diaz-Calvillo P., Rodriguez-Pozo J.A., Cuenca-Barrales C., Martinez-Lopez A., Arias-Santiago S., and Molina-Leyva A. (2021): The Burden of Hidradenitis Suppurativa Signs and Symptoms in Quality of Life: Systematic Review and Meta-Analysis. Int. J. Environ. Res. Public Health, 18 : $6709 . \quad$ https:// doi.org/10.3390/ijerph18136709

15. Nguyen, T.V and Damiani, G. (2021): Orenstein, L.A.V.; Hamzavi, I.; Jemec, G.B. Hidradenitis suppurativa: An update on epidemiology, phenotypes, diagnosis, pathogenesis, comorbidities and quality of life. J. Eur. Acad. Dermatol. Venereol., 35, $50-61$.

16. Peluso, R., Caso, F., Tasso, M., Sabbatino, V., Lupoli, R., Dario Di Minno, M. N., Ursini, F., Costa, L., \& Scarpa, R. (2019): Biomarkers of subclinical atherosclerosis in patients with psoriatic arthritis. Open access rheumatology : research and reviews, 11, 143156. https://doi.org/10.2147/OARRR.S206931.

17. Pink AE, Simpson MA, Desai MA, Trembath RC and Barker JN (2013): $\gamma$ Secretase mutationsin hidradenitis suppurativa: New insights into disease pathogenesis. J Invest Dermatol., 133: 601607.

18. Prens E and Deckers I (2015): Pathophysiology of hidradenitis suppurativa: An update. J Am Acad Dermatol., 73(5 Suppl 1):S8-S11.

19. Takahashi $H$, Iinuma $S$, Honma $M$ and Iizuka H. (2014): Increased serum C-reactive protein level in Japanese patients of psoriasis with cardio- and cerebrovascular disease. $\mathrm{J}$ Dermatol., 41(11):981-5. 
20. Tzellos T, Zouboulis CC, Gulliver W, Cohen AD, Wolkenstein $P$ and Jemec GB (2015): Cardiovascular disease factors in patients with hidradenitis suppurativa: a systemic review and meta-analysis of observational studies. $\mathrm{Br} \mathrm{J}$ Dermatol., 173:1142-1155.

21. Vazquez BG, Alikhan A, Weaver AL, Wetter DA and Davis MD. (2013): Incidence of hidradenitis suppurativa and associated factors: a population-based study of Olmsted County, Minnesota. J Invest Dermatol., 133:97-103.

22. Wang B., Yang W., Wen W., Sun J., Su B., Liu B., Ma D., Lv D., Wen Y., Qu T. Chen
M, Sun M, Shen $Y$ and Zhang X (2010): Gamma-secretase gene mutations in familial acne inversa. Science, 330, 1065.

23. Yayan J. (2012): Erythrocyte sedimentation rate as a marker for coronary heart disease. Vascular health and risk management, 8, 219223. https://doi.org/10.2147/VHRM.S29284

24. Zouboulis CC, Desai N, Emtestam L, Hunger RE, Ioannides D, Juhász I, Lapins J, Matusiak L, Prens EP, Revuz J, Schneider-Burrus S, Szepietowski JC, van der Zee HH, Jemec GBE (2015): European S1 guideline for the treatment of hidradenitis suppurativa/acne inversa. J Eur Acad Dermatol Venereol., 29:619-44. 
معدل تصلب الثرا بين التحت اكلينيكي بين المرضى بالتهاب

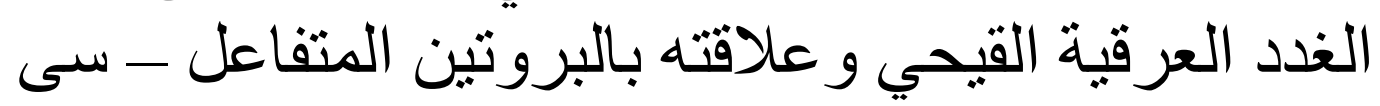

سارة احمد جلال، اسلام محمود محمد عبد المحسن، عبير مصطفى كامل، هالة مغربي مغربي*

قسم الجلاية والتناسلية وقسم الاشعةثة، طب بنات الأزهر

E-mail: drsaragalal@azhar.edu.eg

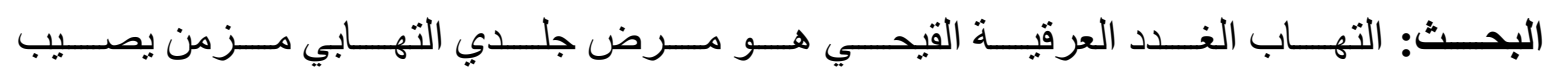

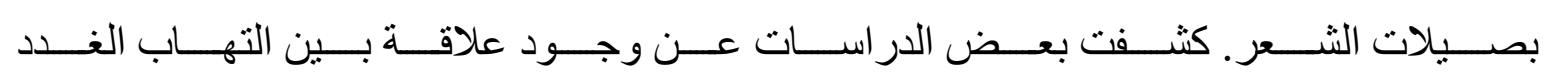

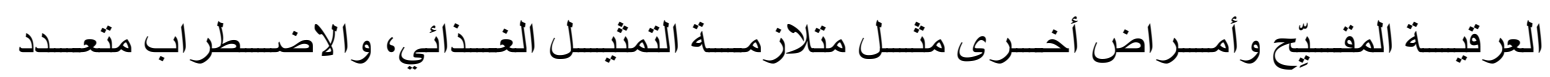

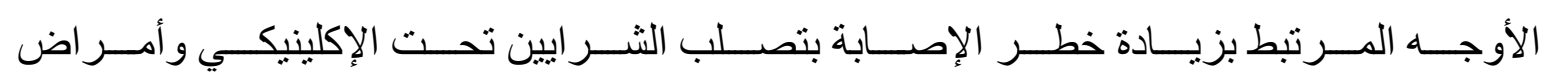
القلب و الأوعية الدموية. - مئ.

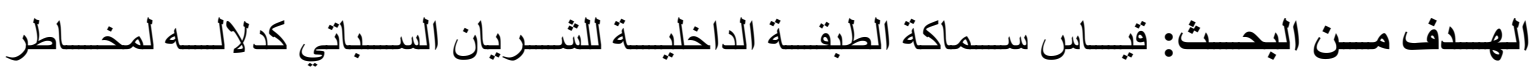

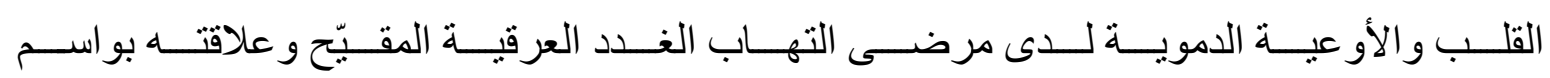
المصل الالتهابي وخاصة بروتين سي التفاعلي.

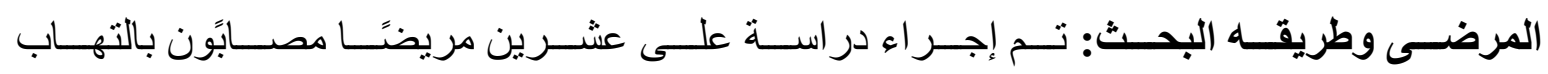

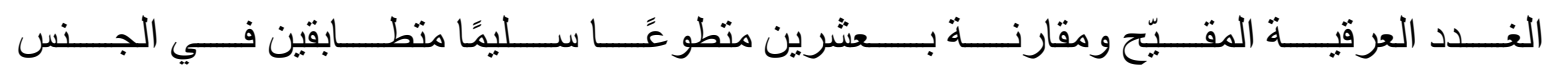

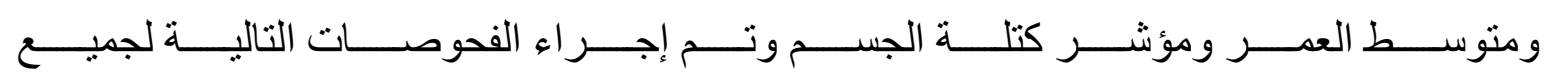

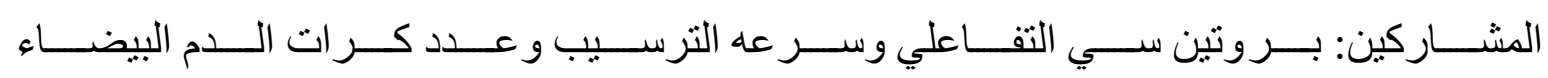

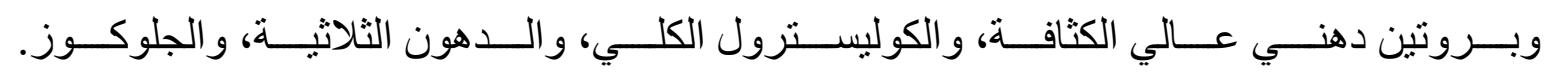

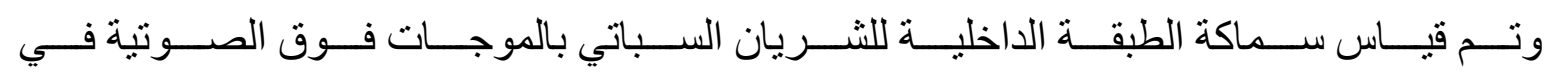
الوضع.

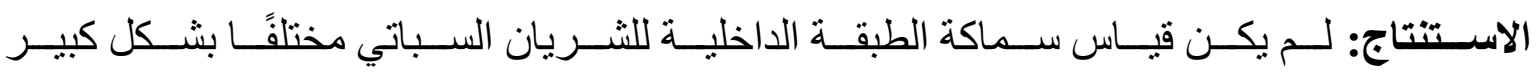

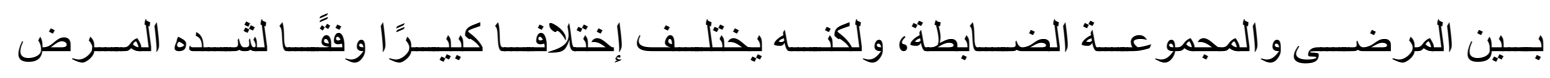

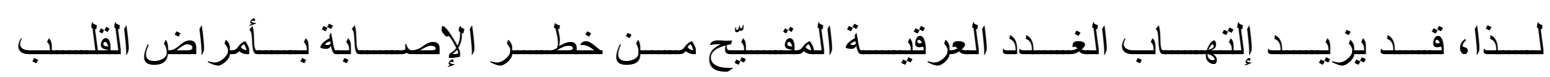

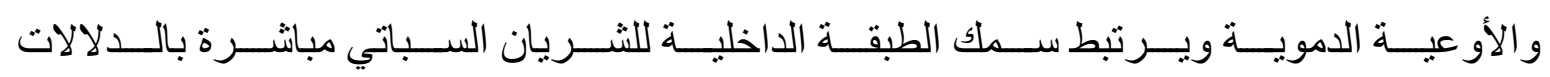


ASSESSMENT OF SUBCLINICAL ATHEROSCLEROSIS IN PATIENTS... 2949

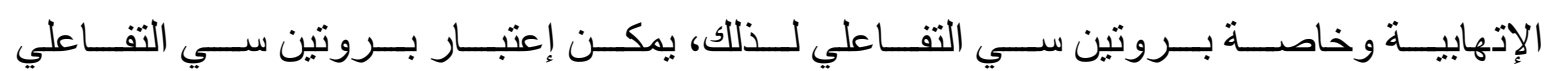
علامة من مؤشر ات شِدة المرض ويمكن إستخدامه لمتابعه الاستجابة للعلاج.

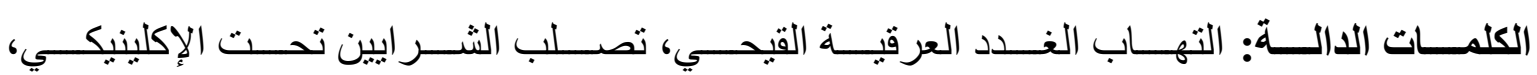

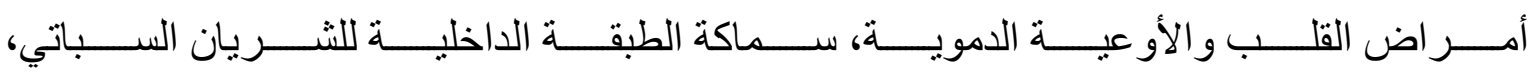
الموجات فوق الصوتية للشريان السباتي. 